\title{
Short Communication: Herpetofauna diversity at the University of Palangka Raya, Indonesia
}

\author{
ANDRI MAULIDI ${ }^{1, \vartheta}$, TITIN PURNANINGSIH ${ }^{2}$, ANITA MAULINA ${ }^{1}$, YOHANES EDY GUNAWAN ${ }^{1}$, \\ MUHAMMAD RIZKI ${ }^{1}$ \\ ${ }^{1}$ Department of Biology, Faculty of Mathematics and Natural Sciences, Universitas Palangka Raya. Jl. Hendrik Timang, Palangka Raya 74874, Central \\ Kalimantan, Indonesia. Tel.: +62-536-4272066, `email: andrimaulidi@mipa.upr.ac.id \\ ${ }^{2}$ Biology Education Program, Faculty of Teacher Training and Education Faculty, Universitas Palangka Raya. Jl. DMG. Salilah I, Palangka Raya 74874, \\ Central Kalimantan, Indonesia
}

Manuscript received: 23 June 2020. Revision accepted: 8 September 2020.

\begin{abstract}
Maulidi A, Purnaningsih T, Maulina A, Gunawan YE, Rizki M. 2020. Short Communication: Herpetofauna diversity at University of Palangka Raya, Indonesia. Biodiversitas 21: 4509-4514. Research on herpetofauna at the University of Palangka Raya (UPR) is vital as there has been no official data so far and remains to be anecdotal evidence from various members of the university. The present study aimed to analyze and report the herpetofauna diversity on the Tunjung Nyaho Campus. It was conducted between October 2019 and November 2019. Herpetofauna data were collected using the Visual Encounter Survey (VES) method. Diurnal and nocturnal surveys were carried out between 07:00-10:00 and 19:00-22:00, respectively. The results showed that as many as 12 species of herpetofauna were present, including six species of reptiles from six families and six species of amphibians from four families. Comparative diversity analyses of these species, unburned, post-burnt, and around building, indicated that the unburned area had a relatively high diversity (2.06) compared to the other two (0.86 and 0.88 , respectively). However, the evenness index (E) for the herpetofauna community in all three locations was $>0.70$. The resulting species list from this study consisted of two species with threatened statuses under the IUCN Red List, i.e., Ophiophagus hannah (VU), and Cuora amboinensis (EN).
\end{abstract}

Keywords: Burnt forest, campus, herpetofauna conservation, land-use change, Palangka Raya

\section{INTRODUCTION}

Research related to the diversity of herpetofauna (amphibians and reptiles) has been carried out on several campuses in Indonesia, including Sriwijaya University (Saptalisa et al. 2015), Sam Ratulangi University (Lindo et al. 2019), Yogyakarta State University (Adhiaramanti and Sukiya 2016), and Semarang State University (Rahayuningsih and Abdullah 2012). Besides, biodiversity studies have been carried out on campuses in several other countries such as Dodoma University, Tanzania (Vats and Safari 2014), Barkatullah University, India (Manhas 2016), Universiti Malaysia Terengganu Campus (Badli-Sham et al. 2019). These studies indicated that universities could play an essential role in recording and maintaining the diversity of herpetofauna in several areas, as well as contributing to the biodiversity data and species lists and occurrences in the region.

As most biodiversity surveys and research are carried out in natural habitats, similar work carried out on university campuses could shed light on herpetofauna presence in anthropogenically modified and urban areas. Land modifications and urbanization also contribute to different responses and adaptive strategies of herpetofauna in a given area. It can also impact the numbers or the species present in such regions, potentially indicating environmental health (Janiawati et al. 2015; Janiawati et al. 2016; Samitra and Rozi 2020). For instance, a study by
Andrews et al. (2008) showed that the presence of roads in a specific habitat could lead to a decrease in reptile abundance in the area.

University of Palangka Raya (UPR) is a governmentsupported university in Central Kalimantan, Indonesia. It has an area of about 5,350 ha divided into three areas, namely the Tunjung Nyaho Campus (300 hectares), Kartini Campus (50 ha), and the Research and Education Forest in Hampangen (5,000 ha). The Tunjung Nyaho campus has a green campus as $\pm 5 \%$ of the land is used for academic, research, student affairs, and about $\pm 95 \%$ area is green space. Recently, UPR established a five-year plan (20202024) to develop the university in becoming the leading research-based institution in the province. In support of that plan, construction of the Center for Science and Technology Development and Peat Innovation began in January 2020. The structure of the new UPR building has considered the balance of land use to prevent environmental damage in improving campus facilities and infrastructure. Therefore, necessary data on the existence of biodiversity on campus is needed to inform the direction of management policies and conservation priorities around the UPR campus and maintain a green campus.

Information regarding the diversity of herpetofauna on the Tunjung Nyaho campus has never been reported. This study aimed to analyze and report the variety of herpetofauna on the campus, taking into account different land uses and habitat types on the campus. The results of this 
study are expected to provide input for better environmental management around the university land area.

\section{MATERIALS AND METHODS}

\section{Study area}

The study was conducted at the Tunjung Nyaho campus, UPR, Central Kalimantan, Indonesia (Figure 1). The area was divided into three sites based on the habitat types: (i) post burned area; (ii) around the building; (iii) unburned area (Figure 2). The post-burn area refers to the area of the university campus that was affected by severe fires in August 2019. The around buildings are areas on campus with many university buildings, and the unburn area refers to a secondary forest that is mostly dominated by Cratoxylum glaucum, Combretocarpus rotundatus, Melaleuca cajuputi, and Acacia mangium.

\section{Data collection}

Data were collected in October-November 2019 using the Visual Encounter Survey (VES) method with a timeconstrained search (Doan 2003). The VES method was used to capture species of animals based on direct encounters on a transect in both terrestrial and aquatic areas. Data collection, at each sampling location, was done twice, between 07:00-10:00 (to find diurnal herpetofauna) and 19:00-22:00 (for nocturnal herpetofauna). Abiotic factors measured in this study were temperature, water $\mathrm{pH}$, and soil pH. A team of seven people conducted the surveys, and three repeated surveys were conducted at each location. Herpetofauna was identified using specialized field guides (Inger et al. 2017; Stuebing et al. 2014). Some of the species found during nocturnal surveys were captured and taken to the laboratory to be photographed during daylight hours. After taking photos, the samples were released back at the same site (where they were captured). All species of herpetofauna were checked against the International Union for the Conservation of Nature (IUCN) Red List to obtain their current conservation status.

\section{Data analysis}

The Shannon-Wiener Index (H’) (Krebs 1978) was used to analyze the data and identify the species diversity index. The evenness Index (E) was calculated to determine the degree of evenness of species at the study site.

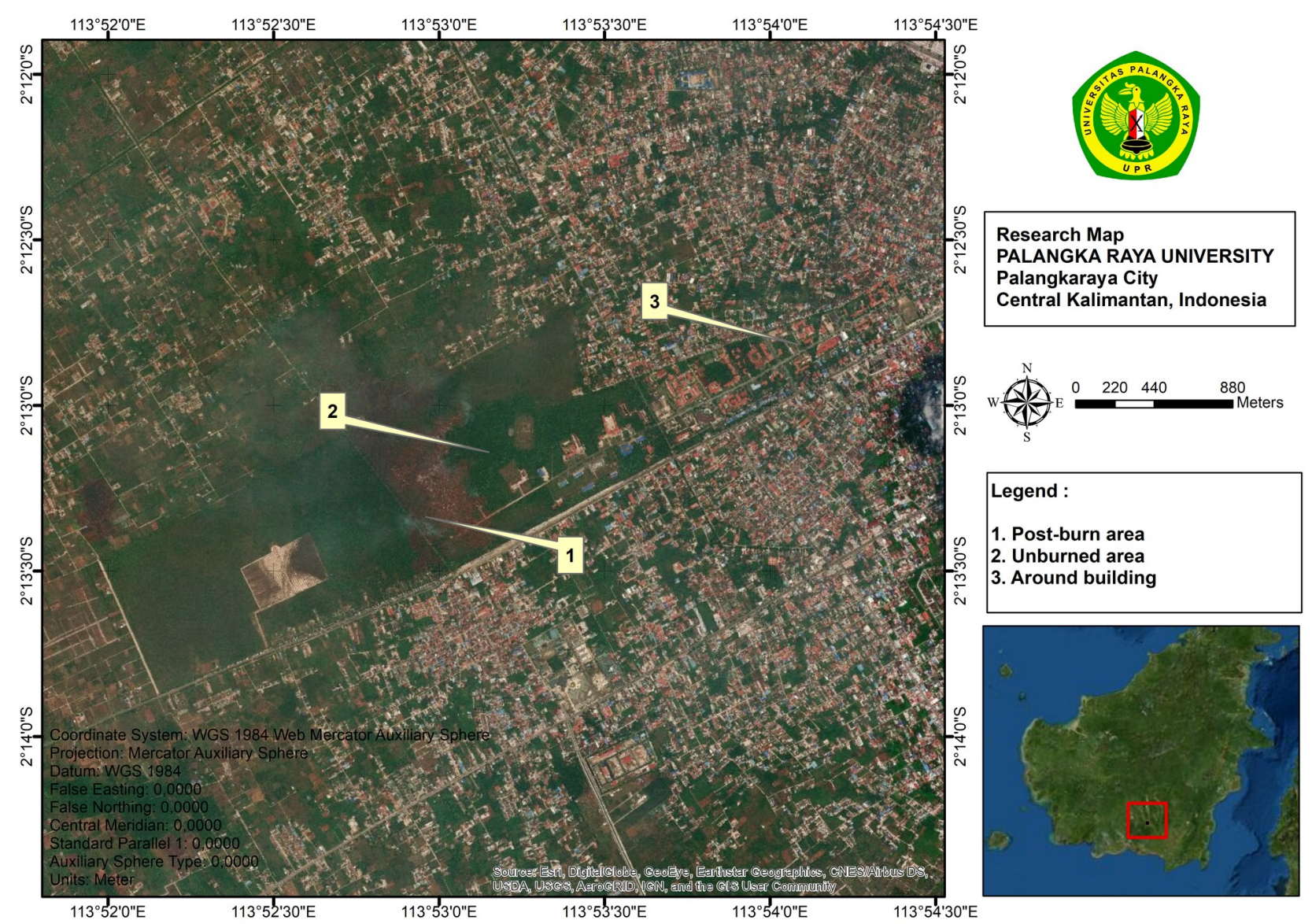

Figure 1. Research area in University of Palangka Raya, Central Kalimantan, Indonesia 


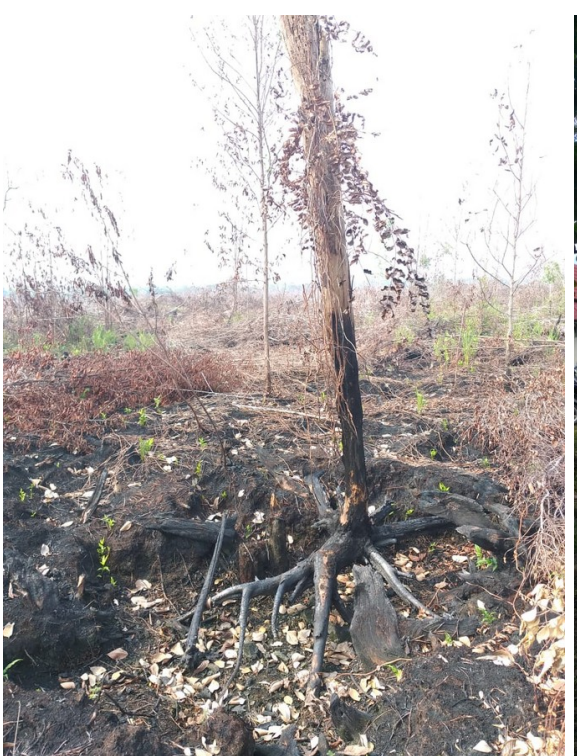

A

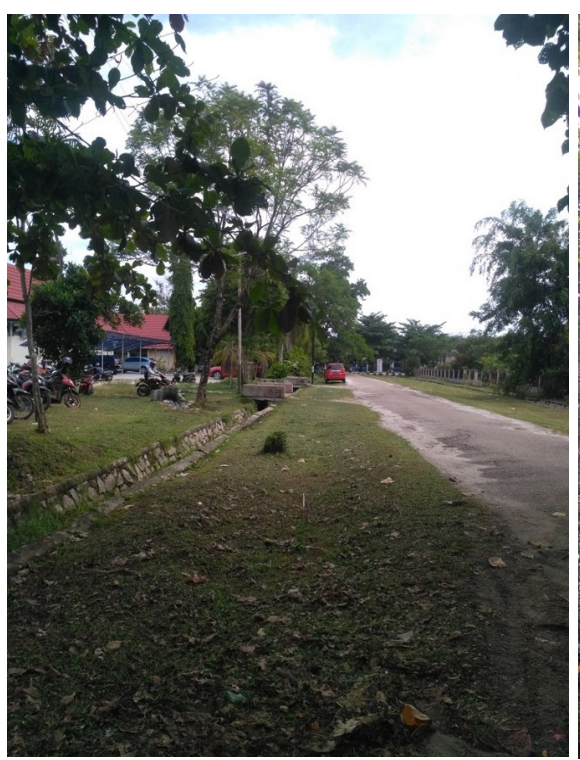

B

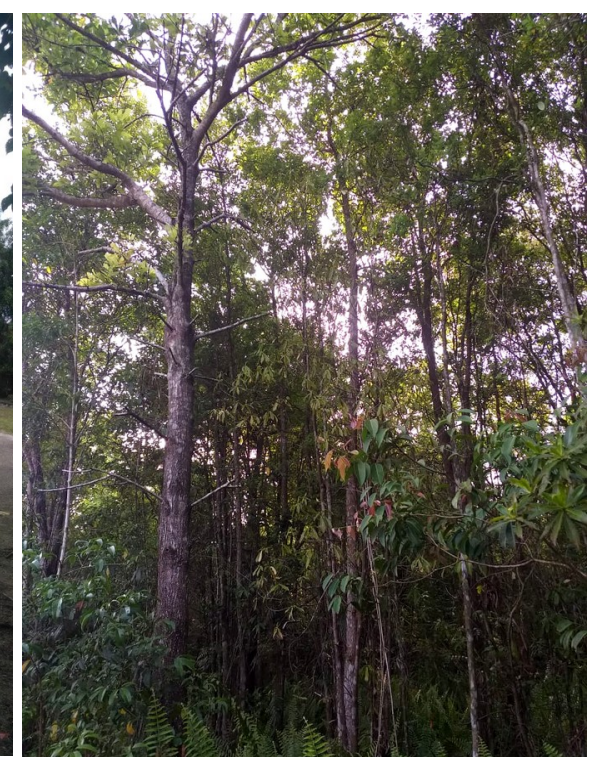

$\mathbf{C}$

Figure 2. Habitat type at three observation sites, University of Palangka Raya, Central Kalimantan, Indonesia: A. Burned area, B. Around building, C. Unburned area

\section{RESULTS AND DISCUSSION}

During the survey, 12 species of herpetofauna were found, consisting of six reptile species from six families and six amphibian species from four families (Table 1). Photographs of a selection of these species are shown in Figure 3. Of these species, one is currently categorized as vulnerable by the IUCN, Ophiophagus hannah, and one as endangered, Cuora amboinensis.

The highest number of species occurred in the unburned area (10). The other two locations had only three species each (Table 1). Only the frog (Fejervarya carnivora) was found at all three locations. Two species were found in both the unburned area and the post-burnt area, namely Hylarana erythraea and Polypedates leucomystax. The most significant number of individual reptiles and individuals were found in the post-burnt area (55 individuals), followed by unburnt area (as many as 30 individuals) and residential locations or around buildings (19 individuals). A large number of individuals in the postburnt area is likely related to the presence of a human-made canal, serving as a water source in the event of a wildfire. The presence of this water source probably explains the high numbers of $F$. cancrivora and $H$. erythraea captured at this location.

Table 1. List of herpetofauna found at the University of Palangka Raya, Central Kalimantan, Indonesia

\begin{tabular}{|c|c|c|c|c|c|c|}
\hline \multirow[b]{2}{*}{ Family } & \multirow[b]{2}{*}{ Spesies } & \multirow[b]{2}{*}{ Common name } & \multirow[b]{2}{*}{ IUCN } & \multicolumn{3}{|c|}{ Location } \\
\hline & & & & $\begin{array}{c}\text { Post-burned } \\
\text { area }\end{array}$ & $\begin{array}{l}\text { Around } \\
\text { building }\end{array}$ & $\begin{array}{c}\text { Unburned } \\
\text { area }\end{array}$ \\
\hline \multirow[t]{2}{*}{ Ranidae } & Hylarana erythraea & Common Green Frog & $\mathrm{LC}$ & 18 & & 5 \\
\hline & Pulchrana baramica & Baram River Frog & $\mathrm{LC}$ & & & 6 \\
\hline Dicroglossidae & Fejervarya cancrivora & Crab-eating Frog & $\mathrm{LC}$ & 33 & 12 & 6 \\
\hline Rhacophoridae & Polypedates leucomystax & Common Tree Frog & $\mathrm{LC}$ & 4 & & 5 \\
\hline \multirow[t]{2}{*}{ Bufonidae } & Duttaphrynus melanostictus & Southeast Asian Toad & $\mathrm{LC}$ & & 5 & \\
\hline & Ingerophrynus biporcatus & Crested Frog & $\mathrm{LC}$ & & 2 & \\
\hline Scincidae & Eutropis multifasciata & Common Mabuya & $\mathrm{LC}$ & & & 2 \\
\hline Geoemydidae & Cuora amboinensis & Southeast Asian Box Turtle & $\mathrm{EN}$ & & & 1 \\
\hline Elapidae & Ophiophagus hannah & King Cobra & VU & & & 1 \\
\hline Colubridae & Dendrelaphis pictus & Painted Bronzeback & - & & & 2 \\
\hline Pareidae & Pareas carinatus & Keeled Slug-eating Snake & LC & & & 1 \\
\hline Natricidae & Xenochrophis trianguligerus & Red-sided Keelback Water Snake & $\mathrm{LC}$ & & & 1 \\
\hline Total & 12 Species & & & 55 & 19 & 30 \\
\hline
\end{tabular}

Note: LC: Least Concern; VU: Vulnerable; EN: Endangered 


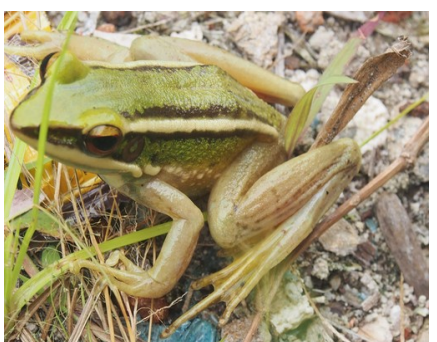

A

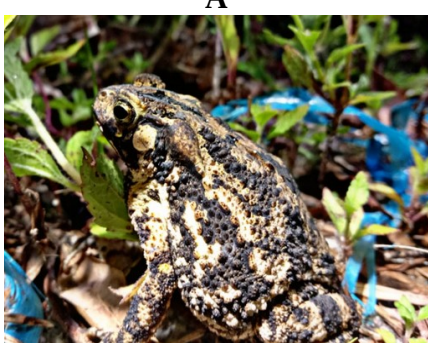

E

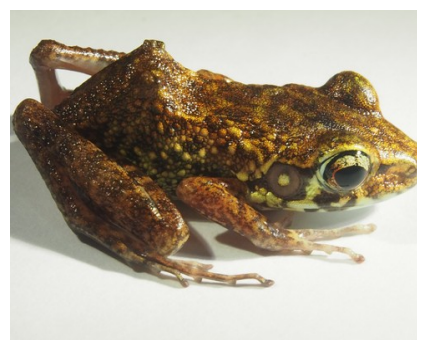

B

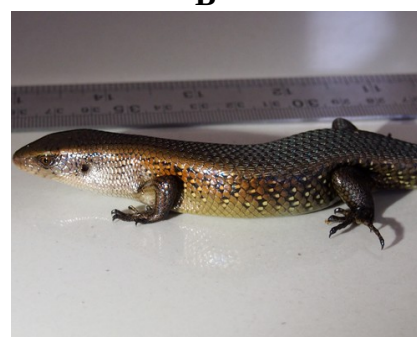

$\mathbf{F}$

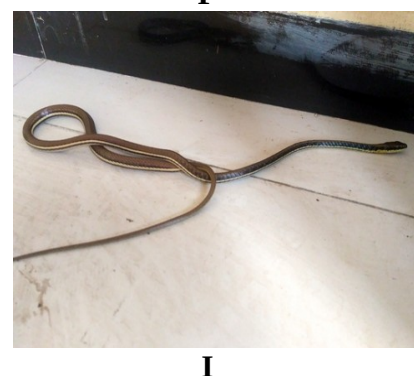

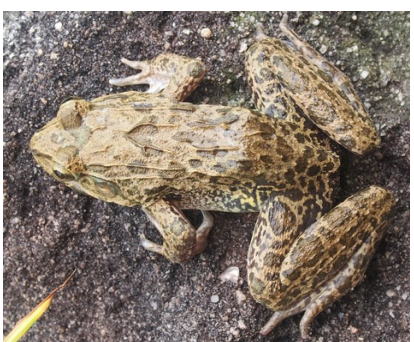

C

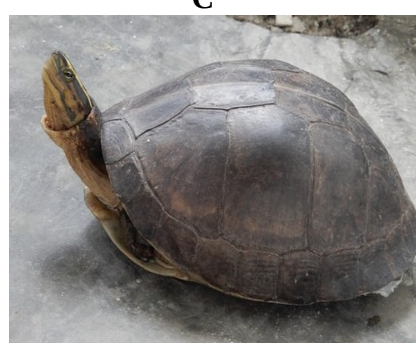

G

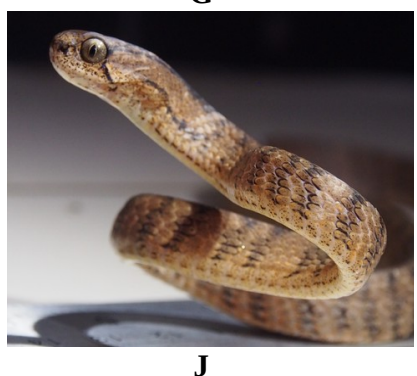

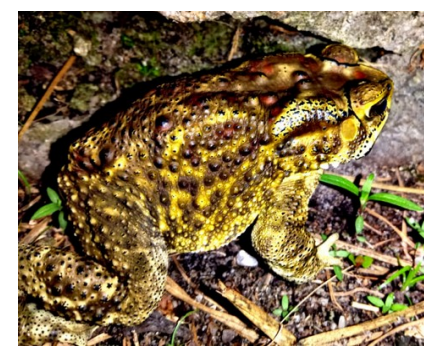

D

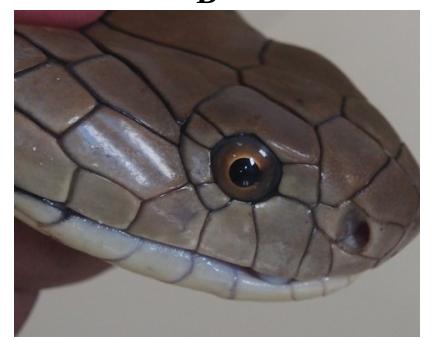

$\mathbf{H}$

Figure 3. Examples of reptiles and amphibians in University of Palangka Raya, Central Kalimantan, Indonesia: A. Hylarana erythraea, B. Pulchrana baramica, C. Fejervarya cancrivora, D. Duttaphrynus melanostictus, E. Ingerophrynus biporcatus, F. Eutrophis multifasciata, G. Cuora amboinensis, H. Ophiophagus hannah, I. Dendrelaphis pictus, and J. Pareas carinatus

Table 2. Diversity and evenness index of Herpetofauna species at University of Palangka Raya

\begin{tabular}{lccc}
\hline Locations name & $\begin{array}{c}\text { Total of } \\
\text { individuals }\end{array}$ & $\begin{array}{c}\text { Diversity } \\
\text { index }\left(\boldsymbol{H}^{\prime}\right)\end{array}$ & $\begin{array}{c}\text { Evenness } \\
\text { index }(\boldsymbol{E})\end{array}$ \\
\hline Post-burned area & 55 & 0.86 & 0.79 \\
Around building & 19 & 0.88 & 0.80 \\
Unburned area & 30 & 2.06 & 0.89 \\
\hline
\end{tabular}

The herpetofauna diversity in this study was quite large compared with herpetofauna research on other campuses. At Sam Ratulangi University, six species of amphibians from the family Bufonidae were reported (Lindo et al. 2019) and Yogyakarta State University had four amphibians species from four families of the order Anura (Adhiaramanti and Sukiya 2016). The present study had fewer species of herpetofauna than that at Semarang State University, where 20 species were consisting of nine amphibian species from four families, and 11 reptile species from five families (Rahayuningsih and Abdullah 2012). These differences in the number of species are likely due to differences in the habitats, length of observation, and the number of observers (surveyors) in the field. The species in this study are still relatively small when compared to the number of species found in the nearby Sebangau National Park, where 11 amphibian species from five families and 46 reptile species from 15 families have been recorded (Husson et al. 2018). These results showed that anthropogenic factors, modifications, and land-use changes impacted the herpetofauna diversity on campus.

\section{The effect of land-use change}

Herpetofauna diversity at University of Palangka Raya can be seen in Table 2. Based on these results, the unburned area has a relatively high diversity compared to the post-burnt area and the area around buildings.

The species evenness index $(\mathrm{E})$ varied across habitat types: the lowest value $(0.79)$ was found in the post-burnt area, followed closely by the area around buildings $(0.80)$. The highest value was observed in the unburnt area (0.89). Environmental factors such as water $\mathrm{pH}$ ranged from 3.264.51 in the unburned area, while it was 5.03-5.08 in the area around infrastructure, and 4.47-4.79 in the burned area. Soil pH was 6.80-7.00 in the unburned area, 6.4-6.6 in areas around buildings, and 6.2-6.4 in the post-burnt area. The surface water $\mathrm{pH}$ in the unburn area was more acidic than the other two locations. The presence of good 
vegetation cover and minimum anthropogenic interference in the unburn area may potentially contribute to it being a relatively suitable area for herpetofauna. However, the high $\mathrm{pH}$ at this location may affect the number of species. Day temperatures ranged from $28^{\circ} \mathrm{C}-31^{\circ} \mathrm{C}$. The temperature was cooled at night and ranged from $24^{\circ} \mathrm{C}-26^{\circ} \mathrm{C}$.

This research showed that disturbances such as forest fires and anthropogenic activities result in low herpetofauna diversity, where common species such as $F$. cancrivora were more abundant in such affected areas. Land changes can play an essential role in herpetofauna presence and diversity. Reptile relative abundance tends to decrease with an increase in the level of modification and water sources and vegetation cover positively correlated with the reptile community (Janiawati et al. 2016)

Another important finding of this study was the vulnerable species, Ophiophagus hannah, and endangered species, C. amboinensis, which were found in the secondary forest habitat area (unburn area). Besides, $O$. hannah is a venomous snake that can cause neurotoxicity. This finding also contributes to university health and safety protocols, where people around the campus need to be vigilant, especially around areas with vegetation cover. However, there have been no reports of venomous snake bites in the campus area. Besides, the finding is interesting as this species is widely distributed in Indonesia. It can encourage further studies of the species in possible speciation as it was identified in Thailand (Suntrarachun et al. 2014) and specific antivenom-related research on $O$. hannah as geographic differences which can affect the potency of the different anti-venoms used in treatment (Tan et al. 2020).

Concerning the conservation status of species found in the survey areas, Cuora amboinensis was categorized as vulnerable by the IUCN Red List in 2000. However, in 2020, the status of the species was changed to endangered species (Cota et al. 2020). Cuora amboinensis can be found in natural and artificial habitats (Diesmos et al. 2008), making it possible to find the species in the campus area. Reports from people on campus indicated that this species was frequently seen here. In Central Kalimantan, $C$. amboinensis is consumed by local communities (Fauzi et al. 2020). In contrary to its status, this species is not protected under wildlife laws in Indonesia. Also, Indonesia is a major supplier of both living individuals and the carapace of these species, thus, requiring attention and monitoring of the illegal and legal trade (Fauzi et al. 2020) as well as the protection of this species in areas present.

The results suggested that further construction and changes in land cover will have to take into account the diversity of herpetofauna and the natural areas inhabited by sensitive and vulnerable species to safeguard and sustain the existing species and maintain the status of a green campus. At Sriwijaya University, there are also similar disturbances, such as burning grasslands, destroying habitats, and cutting large trees (Saptalisa et al. 2015). It is essential to take notice of threats to these species and their habitats such as random land clearing for infrastructure and land fires that the university suffered from in the past. The campus should prioritize this aspect as species are likely to be more disturbed if there are widespread land fires or land clearing of the existing green spaces.

Information on the presence of herpetofauna at the UPR can be an indicator of damage to an ecosystem, as these species are sensitive to land-use changes and other ecological disturbances (Burlibaşa and Gavrilacaron 2011; Priambodo et al. 2019; Stuart et al. 2004). Apart from being an environmental indicator, amphibians and reptiles also have an important role in the food web both as predators and prey (Howell 2002).

Another threat to herpetofauna on the Tunjung Nyaho Campus of University of Palangka Raya is the killing of snakes that are not necessarily venomous (e.g., the killing of Dendrelaphis pictus outside the observation schedule) due to fear of being bitten. This condition also happened in India at Orissa University, where venomous and nonvenomous snakes were killed when found (Boruah 2017). One primary reason is that people are unable to distinguish between venomous and non-venomous snakes, therefore resulting in their death (Vats and Safari 2014). Based on preliminary information, such as in this study, data can be used to create on-campus activities and workshops focusing on how to distinguish venomous from nonvenomous snakes. Also, the role of snakes in the balance of the ecosystem needs to be explained to build awareness among people on campus. Involving the student body in understanding the threats and importance of herpetofauna can also help in creating more interest in herpetofauna conservation and increase involvement in creating awareness and participation in conservation-related activities within and outside the campus. Through this baseline data of herpetofauna, it is hoped that stakeholders of UPR can collaborate to preserve herpetofauna on campus. It is hoped that this study can be the first among more campus-based biodiversity surveys in the future to encourage the university management to provide land for ex-situ conservation work on campus, especially for the endangered C. amboinensis.

In conclusion through this research, 12 herpetofauna species were recorded on the Tunjung Nyaho campus, including six species of reptiles from six families and six species of amphibians from four families. Vulnerable species such as $O$. hannah and Endangered species such as C. amboinensis were discovered during research in unburned secondary forests. Among the three locations, the highest level of herpetofauna diversity was observed in unburnt secondary forests ( $\mathrm{H}^{\prime}:$ 2.06), and post-burnt land had the lowest diversity ( $\mathrm{H}^{\prime}$ : 0.86). Also, the unburned secondary forest had the highest level of evenness (evenness index 0.89), and post-burnt land had the lowest evenness (evenness index 0.79). Knowing the diversity of herpetofauna, it is hoped that stakeholders at University of Palangka Raya, Central Kalimantan, Indonesia can collaborate to preserve the site's herpetofauna.

\section{ACKNOWLEDGEMENTS}

The authors would like to thank the University of Palangka Raya, Central Kalimantan, Indonesia that 
provided funding for this research through PNBP 2019. They would also like to express their gratitude to the involved students (Ebrry Dwi Putra, Muhammad Hanafi, Mawardin, Wayan Adhi Nareyasa, Dendie, Ade Damara Gonggoli). The latter assisted in taking photos and sampling activities. Thanks also to Wendy Erb, Mark E. Harrison, Namrata, and Anggun for providing content and language suggestions to improve the present manuscript.

\section{REFERENCES}

Adhiaramanti T, Sukiya. 2016. Keanekaragaman Anggota Ordo Anura di Lingkungan Universitas Negeri Yogyakarta. J Biol 5 (6): 62-72. [Indonesian]

Andrews KM, Gibbons JW, Jochimsen DM. 2008. Ecological effects of roads on amphibians and reptiles: a literature review. Herpetol Conserv Biol 3:121e43.

Badli-Sham BH, Shahira-Ibrahim N, Xian GS, Syamila-Noh H, SHUKOR NSAA, SHAFIE FA, Daud NM, Razak FAA, Rosli R, Aziz AAA, et al. 2019. Herpetofauna of Universiti Malaysia Terengganu Campus: Sustaining biodiversity in campus green area. J Sustain Sci Manag 14 (1): $11-28$.

Boruah B, Das GN, Payra A, Dash SK, Pal NS, Das UP, Kar NB, Sethy J, Palei HS, Nandi D. 2016. Diversity of herpetofauna and their conservation in and around North Orissa University Campus, Odisha, India. NeBIO An Int J Environ Biodivers 7 (4): 138-145.

Burlibaşa L, Gavrilacaron L. 2011. Amphibians as model organisms for study environmental genotoxicity. Appl Ecol Environ Res 9 (1): 1-15. DOI:10.15666/aeer/0901_001015.

Cota M, Hoang H, Horne BD, Kusrini MD, McCormack T, Platt K, Schoppe S, Shepherd C. 2020. Cuora amboinensis. The IUCN Red List of Threatened Species 2020: e.T5958A3078812. DOI: 10.2305/IUCN.UK.2020-2.RLTS.T5958A3078812.en

Diesmos, A.C., Brown, R.M., Alcala, A.C. and Sison, R.V. 2008. Status and distribution of nonmarine turtles of the Philippines. Chelonian Conserv Biol 7 (2): 157-177.

Doan TM. 2003. Which methods are most effective for surveying rain forest herpetofauna?. J Herpetol 37 (1): 72-81. DOI:10.1670/00221511(2003)037[0072:wmamef]2.0.co;2.

Fauzi MA, Hamidy A, Kurniawan N. 2020. Harvesting trends of amboina box turtles (Cuora amboinensis) seventeen years after listing in Appendix II Cites. Biodiversitas 21 (3): 1142-1148. DOI: 10.13057/biodiv/d210339.

Howell K. 2002. Amphibians and Reptiles: the herptiles. In: Davies G, editor. African Forest Biodiversity: A Field Survey Manual for Vertebrates. Earthwatch Institute, UK.

Husson SJ, Limin SH, Adul, Boyd NS, Brousseau JJ, Collier S, Cheyne SM, D'Arcy LJ, Dow RA, Schreven S. 2018. Biodiversity of The Sebangau Tropical Peat Swamp Forest, Indonesian Borneo. Mires Peat 22: 5. DOI: 10.19189/MaP.2018.OMB.352.
Inger R, Stuebing R, Grafe T, Dehling J. 2017. A Field Guide to the Frogs of Borneo. 3rd ed. Natural History Publication (Borneo), Kinabalu.

IUCN. 2020. The IUCN Red List of Threatened Species. Version 2020

Janiawati IAA, Kusrini MD, Mardiastuti A. 2015. Structure and composition of amphibian communities in human modified landscape in Gianyar Regency, Bali. J Indon Nat Hist 3 (2): 27-35.

Janiawati IAA, Kusrini MD, Mardiastuti A. 2016. Structure and composition of reptile communities in human modified landscape in Gianyar Regency, Bali. Hayati J Biosci 23 (2): 85-91.

Krebs CJ. 1978. Ecological Methodology. Harper and Row Publisher, New York.

Lindo GK, Katili DY, Wahyudi L. 2019. Keanekaragaman Amphibia di Kampus Universitas Sam Ratulangi. Pharmacon 8 (3): 186-192. [Indonesian]

Manhas A. 2016. An Addition to the Reptilian Diversity of Barkatullah University Campus, Bhopal, Madhya Pradesh, India. Intl J Pure Appl Zool 4 (4): 306-309.

Priambodo B, Permana H, Akhsani F, Indriwati SE, Wangkulangkul S, Lestari SR, Rohman F. 2019. Characteristic of water sources in Malang, based on the diversity, community structure, and the role of herpetofauna as bioindicators. EurAsian J Biosci 13 (2): 2279-2283.

Rahayuningsih M, Abdullah. 2012. Persebaran dan keanekaragaman herpetofauna dalam mendukung konservasi keanekaragaman hayati di Kampus Sekaran Universitas Negeri Semarang. Indonesian J Conserv 1 (1): 1-10. [Indonesian]

Samitra D, Rozi ZF. 2020. Short communication: The herpetofauna around human settlements in Lubuklinggau city, south Sumatra, Indonesia: Composition and diversity. Biodiversitas 21 (4): 14321437. DOI: 10.13057/biodiv/d210422.

Saptalisa W, Yustian I, Setiawan A. 2015. The diversity of reptiles on several habitat types in Campus Area of Sriwijaya University Indralaya, Ogan Ilir. Biovalentia Biol Res J 1 (1): 39-51. DOI: 10.24233/biov.1.1.2015.18.

Stuart SN, Chanson JS, Cox NA, Young BE, Rodrigues ASL, Debra L, Waller RW, Unit ICBA, Street M. 2004. Status and trends of amphibian declines and extinctions worldwide. Science 306 (5702): 1783-1786. DOI: 10.1126/science.1103538.

Stuebing R, Inger R, Lardner B. 2014. A field guide to the snakes of Borneo. 2nd ed. Natural History Publication (Borneo), Kinabalu.

Suntrarachun S, Chanhome L, Sumontha M. 2014. Phylogenetic analysis of the king cobra, Ophiophagus hannah in Thailand based on mitochondrial DNA sequences. Asian Biomed 8 (2): 269-274. DOI: 10.5372/1905-7415.0802.289.

Tan KY, Ng TS, Bourges A, Ismail AK, Maharani T, Khomvilai S, Sitprija V, Tan NH, Tan CH. 2020. Geographical variations in king cobra (Ophiophagus hannah) venom from Thailand, Malaysia, Indonesia and China: On venom lethality, antivenom immunoreactivity and in vivo neutralization. Acta Trop 20 (3): 105311. DOI: 10.1016/j.actatropica.2019.105311.

Vats R, Safari I. 2014. Diversity of snakes at the University of Dodoma Campus, Tanzania. Am J Zool Res 2 (3): 41-45. DOI: 10.12691/ajzr2-3-1. 